\title{
تأثير التدريب الضاغط على مستوى بعض جوانب الاداء الفنى لناشئى كرة القدم احمد نصر مصطفى
}

\author{
اخصائى رياضى بكلية التربية -جامعة الزقازيق
}

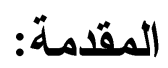

يعتبر التنريب الرياضى عملية تربوية منظمة تخضع للأسس العلمية للوصول باللاعبين للمستويات

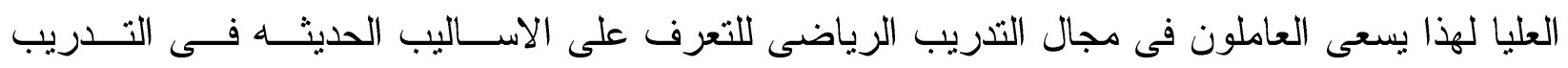
الرياضى وما يصاحبها من نظريات علمية.

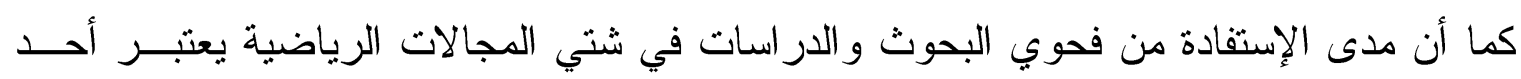

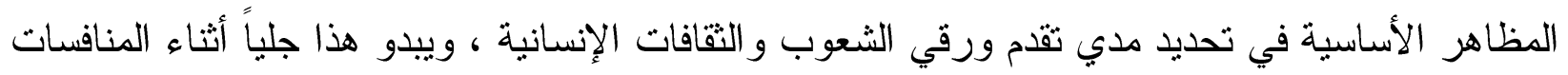

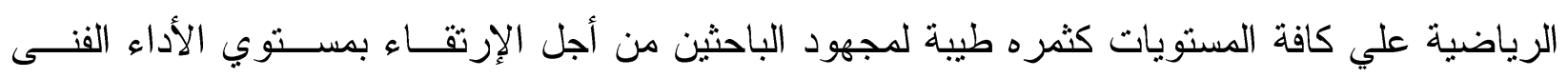

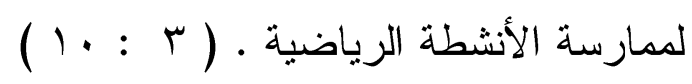

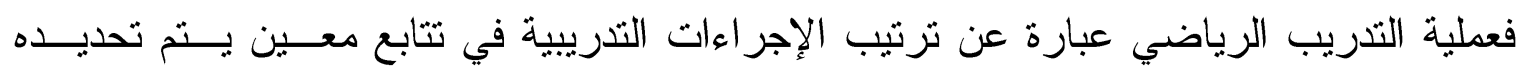

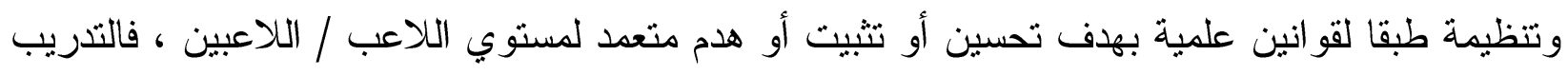

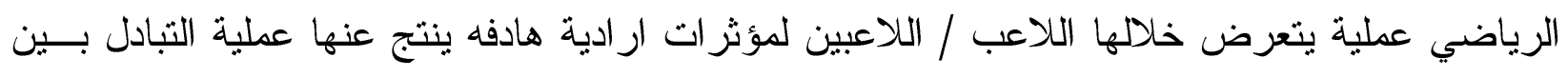

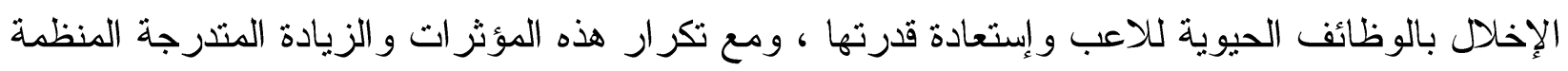

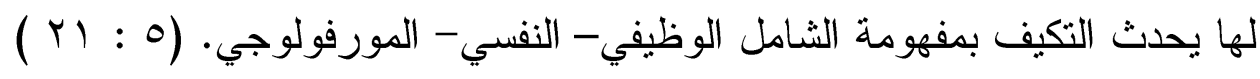

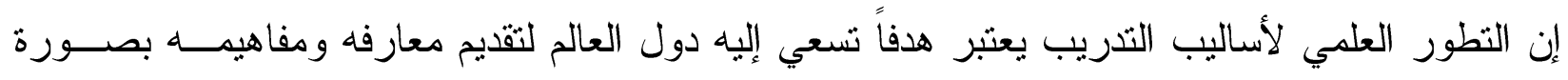

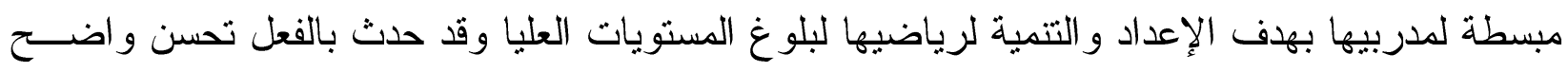

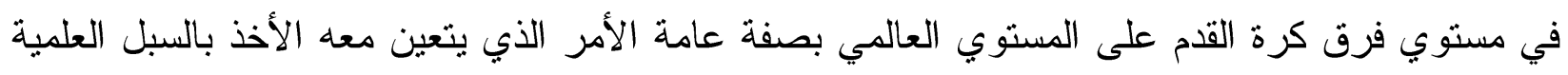

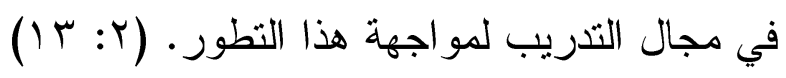

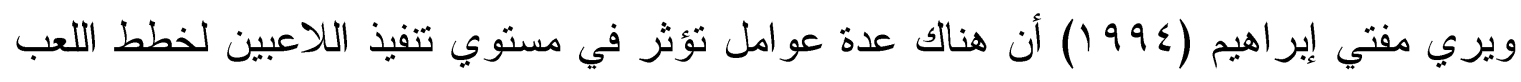

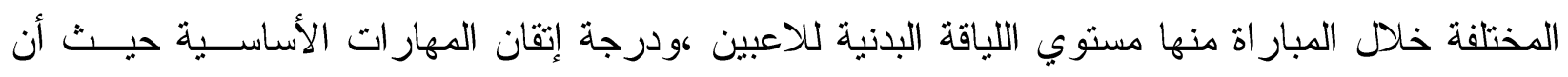

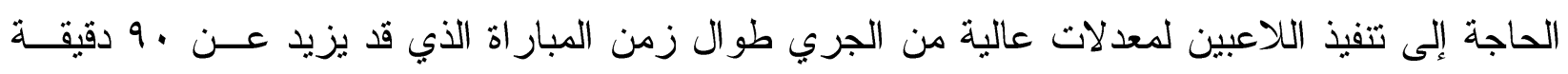

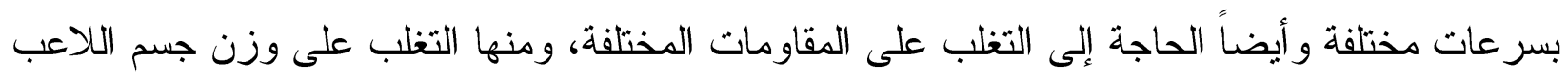

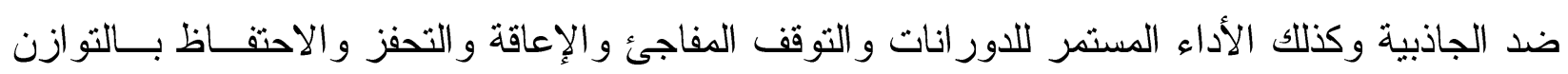


و الاحتكاك البدني مع المتنافسين والكرة والملعب كلها أمور تتطلب إعداداً بدنياً ذا مستوي مرتفع للاعبين، الأمر الذي يمكنهم من تتفيذ خطط اللعب بكفاءة وفاعلية دونما هبوط في مستوي الأداء خلال المبار اة.

ويشير حنفي مختار (99 (1) أنه من الأفضل أن ينم التدريب على المهارات الأساسـية خــلال

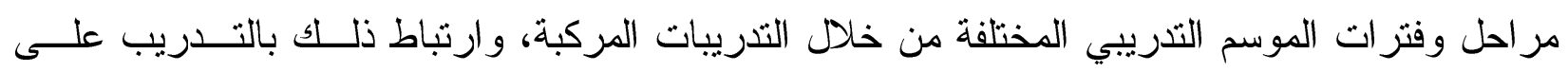

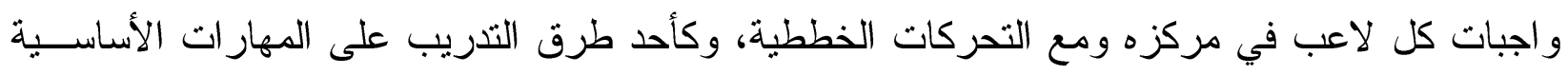

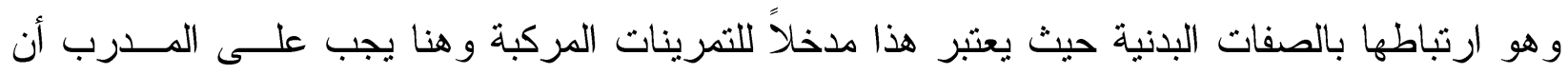

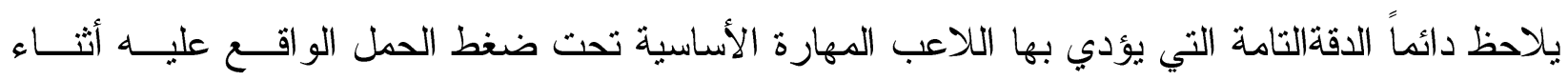

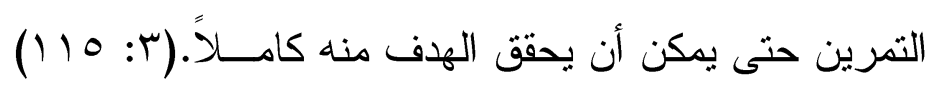

ويتفق كلاً من محمدوقي كشك وأمر الله البساطي (..... أن طبيعة اللعب خلال مباريات كرة

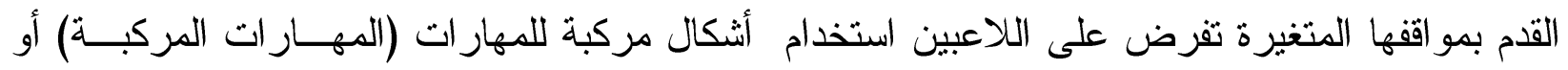

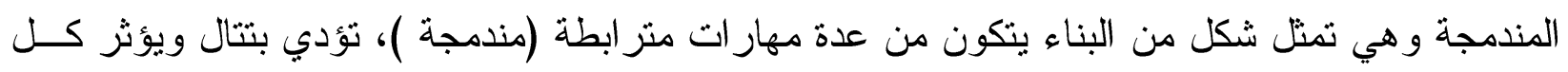

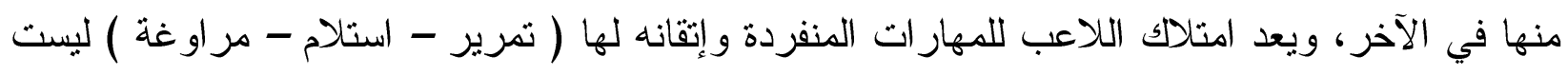

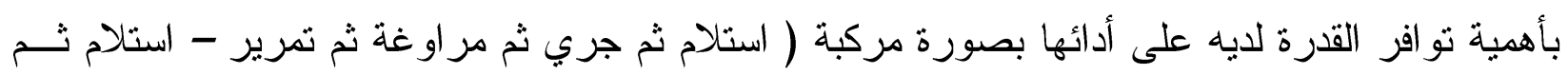

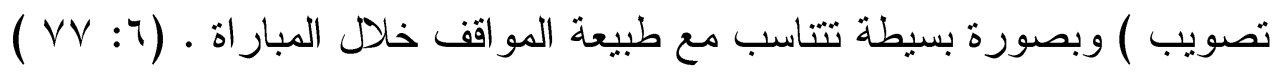
مشكلة البحث.

تشهد كرة القدم تطورا هائلا على المستوى العالمي, إلا أنة يلاحظ عدم قدرة لاعبي الوطن العربي

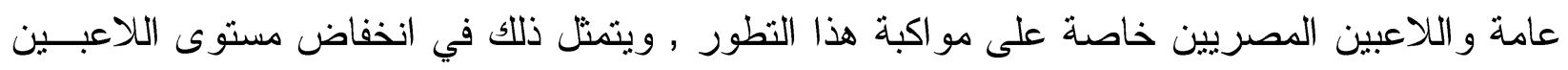

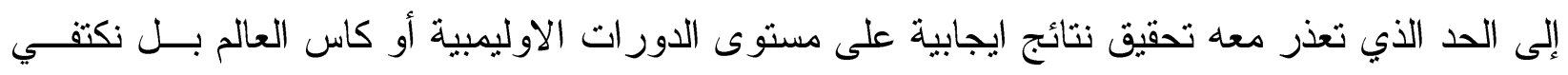
دائما بالتثثيل المشرف في معظم البطولات.

ويشير طه إسماعيل وآخرون (1997) إلى أن التطور الحادث في كرة القدم اخذشكلا جديدا في

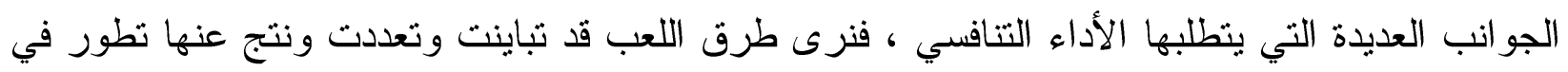

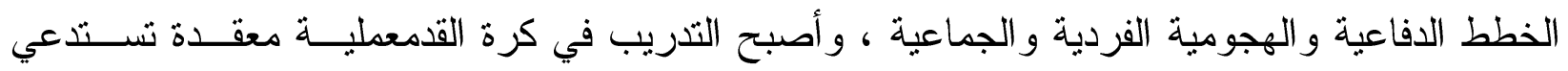

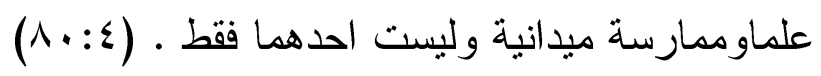


ولكي يحقق لاعب كرة القدم أعلي مستوي من الأداء في اللعب خلال المباريات يجــب أن يعـد

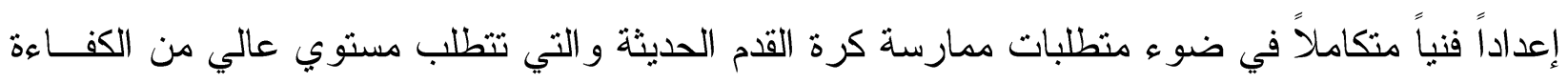

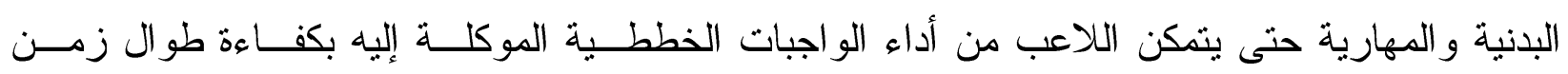

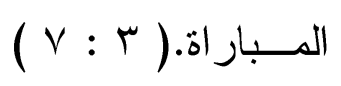

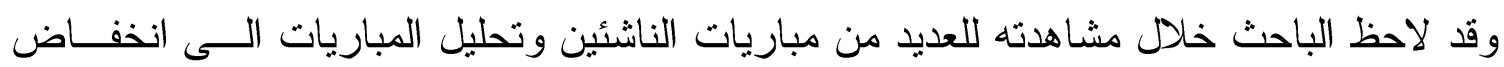

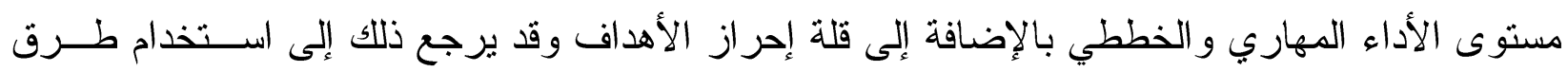

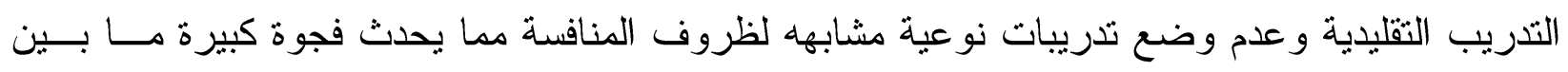
الأداء في التدريب و الأداء في المنافسة حيث يهدف التدريب الضاغط إلى وضع اللاعبين في جو وظروف

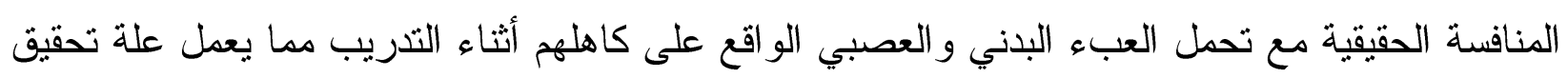

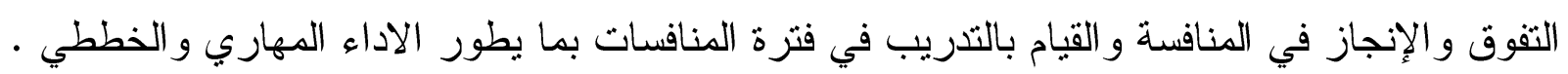

ويعتقد الباحث أن التدريب الضاغط كأحد أساليب التدريب العلمية الحديثة يساعد علــى تطــــير

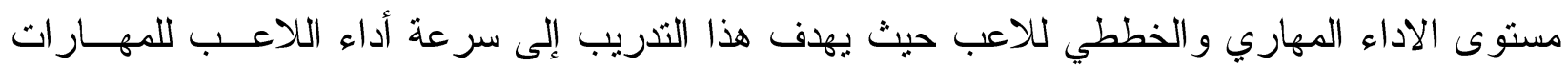
بالدقة المطلوبة وفي نفس الوقت زيادة تحمل اللاعب للأداء المهاري لهذه المهارة وبالتالي نظوير مستوى لناه الاداء المهاري والخططي للأداء بطريقة أفضل أثناء المباريات.

ويعتبر هذا النوع من التدريب له أهمية كبرى للتندريب على المهارة وهو مرتبط بصـفة التحمـلـل

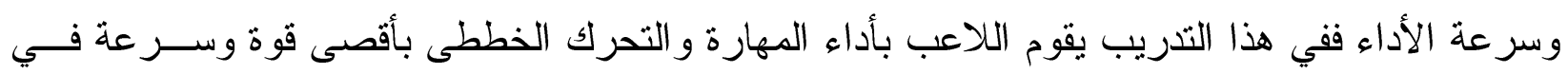

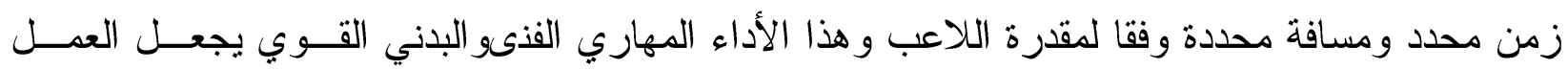
لاهو ائيا و المدرب هو الذي يحدد شدة الحمل التي يؤدي بها اللاعب وذللك وفقا لما يأتي:

- تغيير اتجاه التمرين باستمر ار. - - تغيير المسافة بين اللاعب والكرة. - - تغيير المسافة التي يجريها اللاعب. - - تحديد و التحكم فى المساحة التى يؤدى فيها التدريب.

ويهدف هذا التدريب إلى سرعة أداء اللاعب للمهار ات بالدقة المطلوبة وفي نفس الوقت زيادة تحمل اللاعب للأداء المهاري لهذه المهارة ومن أمتلة هذه الطريقة: 
- مترينات التصويب على المرمى من الاتجاهات المختلفة من الكرات التي تصل للاعب داخل منطقة الجز اء للعبها من أماكن مختلفة - ت تمرينات ضرب الكرة بالر أس عن طريق التمرينات بأكثر من كرة.

وقد قام كثير من الباحثين في مصر و الوطن العربي بإجر اء العديد من الدراسات والأبحاث فــي

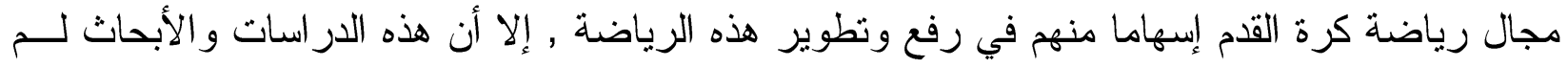
تتطرق إلى الموضو عات المرتبطة بالتّريب الضاغط ومدى تأثيره على الأداء المهاري و الخططي لناشئي كرة القدم موضو ع البحث الحالي (على حد اطلاع الباحث).

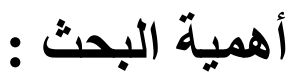

التعرف على تأثير التدريب الضاغط على بعضالمستويات المهارية و الخططية لناشئي كرة القدم. • قلةالأبحاث العلمية (على حد علم الباحث)التى تتناول تصميم برنامج تدريبى بأستخدام التدريب الضاغط وتاثيرة على القدرات المهارية و الخططية و البدنية . • محاولة تطوير الاداء المهاري لناشئي كرة القدم. • محاولة تطوير الاداء الخططي لناشئي كرة القدم.

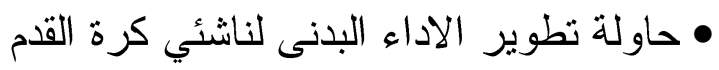
• قد يستقيد الباحثون و المدربون فى مجال التدريب الرياضى لأهمية التذريب الضاغط في تطوير مستوى الأداء الرياضي بصفة عامة. هدف البحث:

\section{يهرف البحث إلى تصميم برنامج للتدريب الضاغط للتعرف على:}

• تأثير التدريب الضاغط على مستوى بعض جو انب الاداءالمهاري لناشئي كرة القدم •

تأثثر التدريب الضاغط على مسنوى بعض جوانب الاداء الخططي لناشئي كرة القدم .

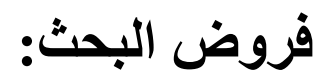

توجد فروق ذات دلالة إحصائية بين القياس القبلي و القياس البعدي لمستوى بعض جو انب الأداء المهاري لناشئي كرة القدم. توجد فروق ذات دلالة إحصائية بين القياس القبلي و القياس البعدي لمستوى بعض جوانـبـ الاداء الخططي لناشئي كرة القدم. 
• توجد فروق ذات دلالة إحصائية بين القياس القبلي و القياس البعدي لمستوى بعض جو انـب الاداء البدنى لناشئي كرة القدم.

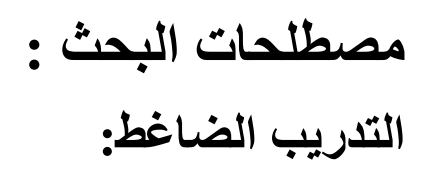

هو تدريب يقوم فيه اللاعب بأداء جو انب الأداء الفني (مهاري - خططي ) بأقصى قوة وسرعة في أقــل

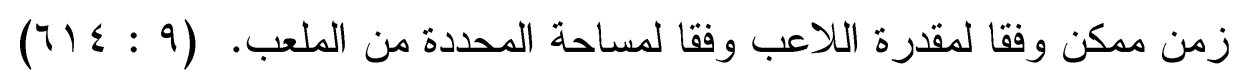


الاراسات السابقة :

\begin{tabular}{|c|c|c|c|c|c|c|}
\hline أهم النتائج & المنهج & العينــة & أهداف البحث & عنوان البحث & اسم الباحث & م \\
\hline 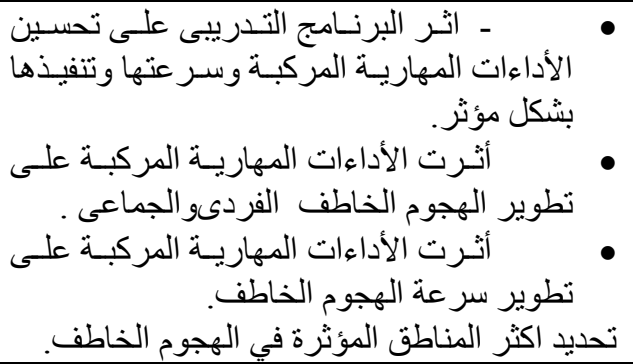 & التجريبى & • سنة. & 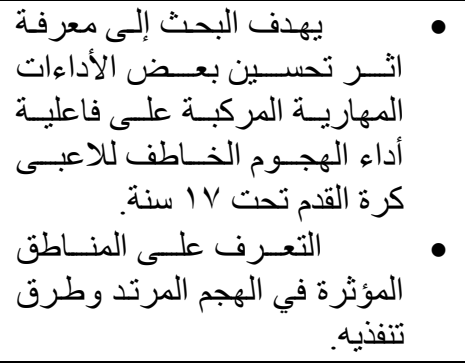 & 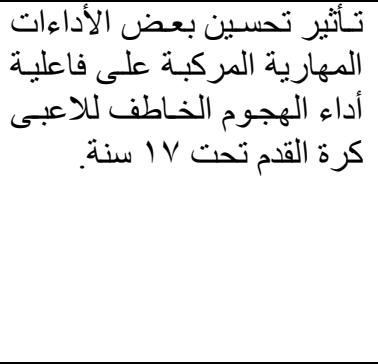 & الشريف عبد الجليل & 1 \\
\hline 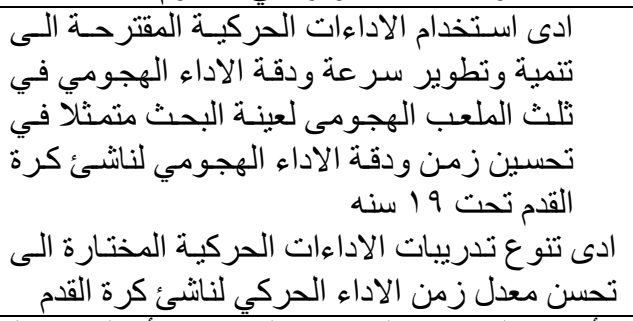 & التجريبى & •0 ناثشئ تحت 9 اسنة. & 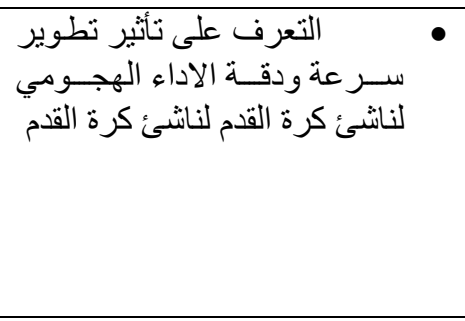 & 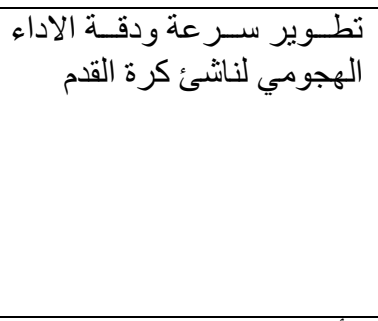 & 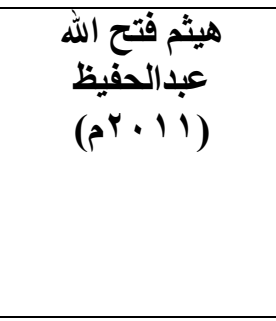 & $r$ \\
\hline 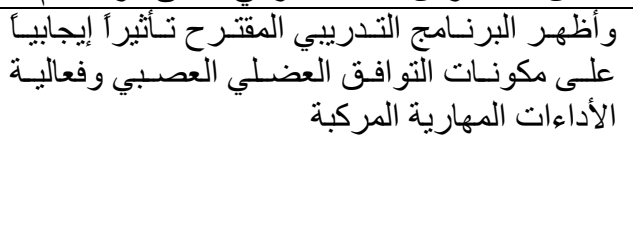 & التجريبي & 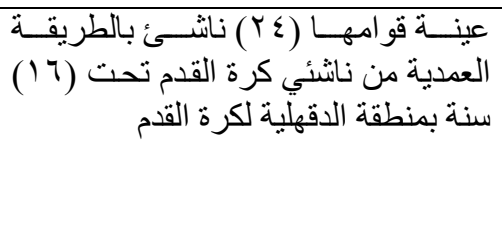 & 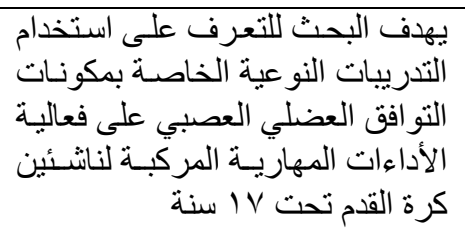 & 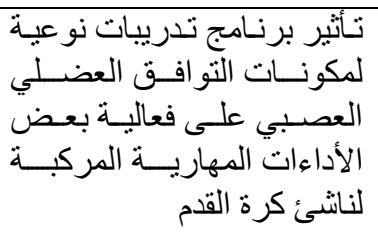 & إسلام مسعد علي & $r$ \\
\hline
\end{tabular}




\begin{tabular}{|c|c|c|c|c|c|c|}
\hline أهم النتائج & المنهج & العينــة & أهداف البحث & عنوان البحث & اسم الباحث & م \\
\hline 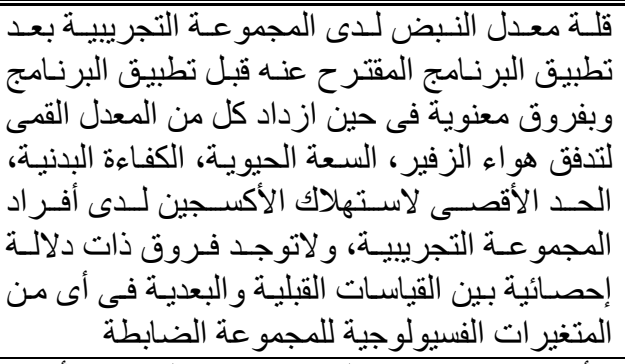 & التجريبى & 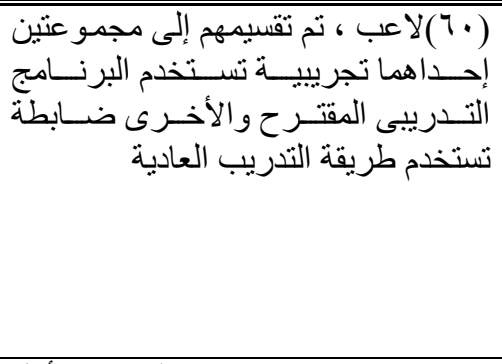 & 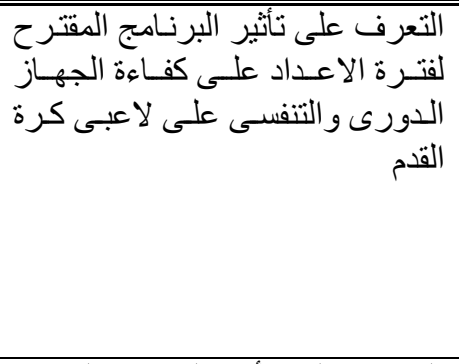 & 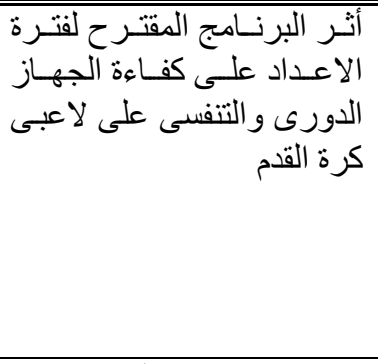 & 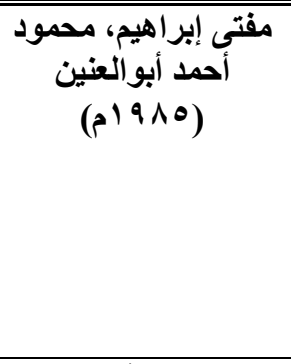 & $\varepsilon$ \\
\hline 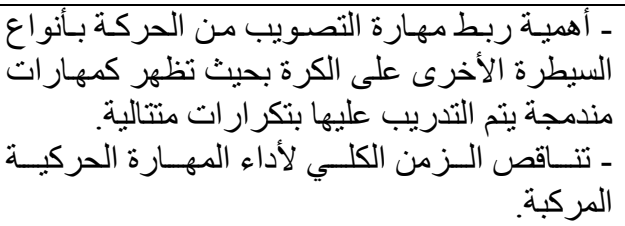 & التجريبي & 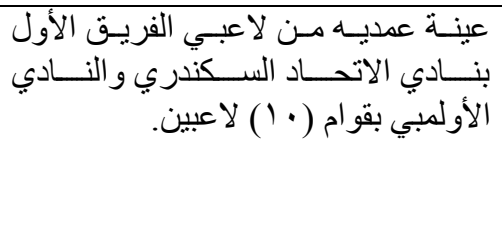 & 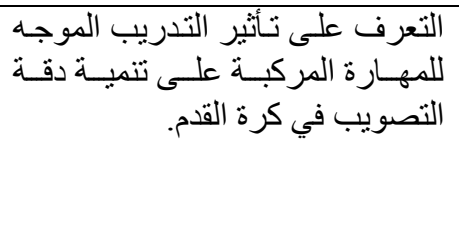 & 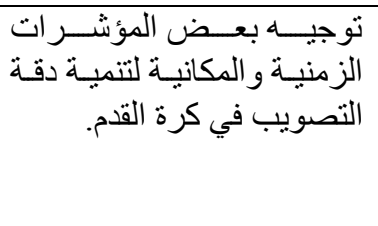 & محمد شوقي كثكك ( ) ( ) & 0 \\
\hline 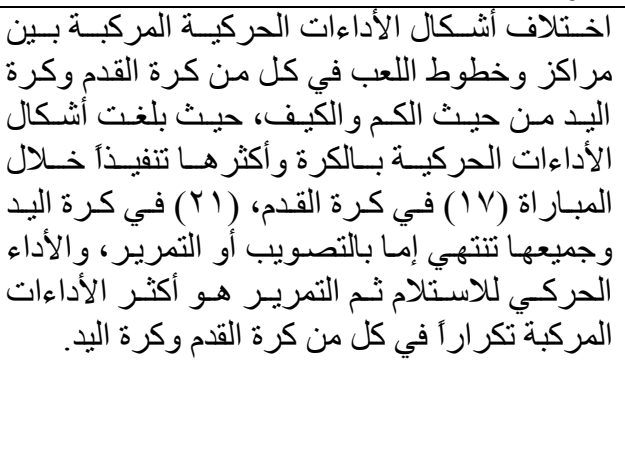 & الوصفي & 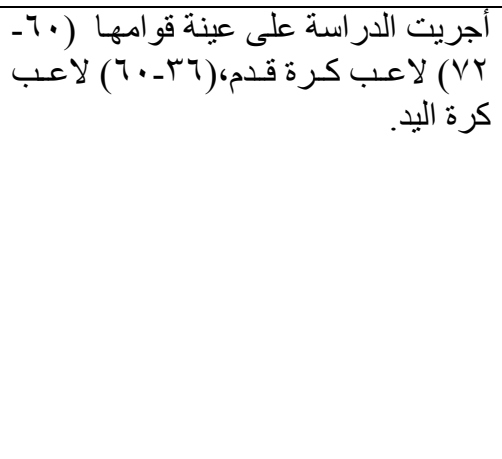 & 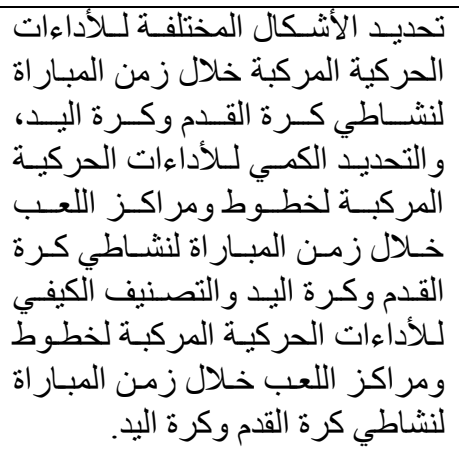 & 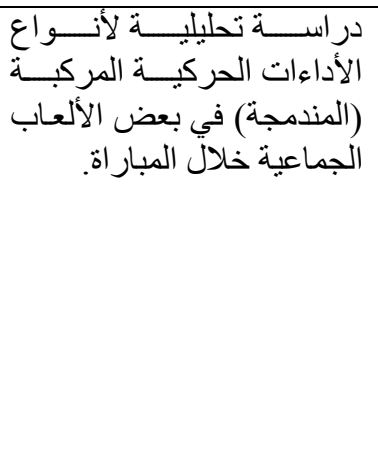 & أمر الله أحمد البساطي & 7 \\
\hline
\end{tabular}




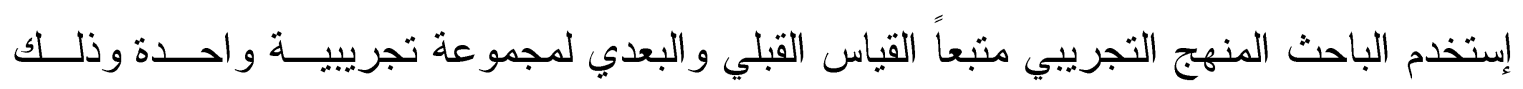
لملائمته لطبيعة هذا البحث.

مجتمع البحث :تم إختيار مجتمع البحث من ناشئي كرة القدم بمحافظة الثرقية والمسلين بالاتحاد المصرى لكرة القدم.

\section{عينة البحث : عزم:}

تم اختيار عينة البحث من لاعبين مركز شباب ابوحماد بمدينة ابوحماد مو اليد ع .. بام وقد قـام

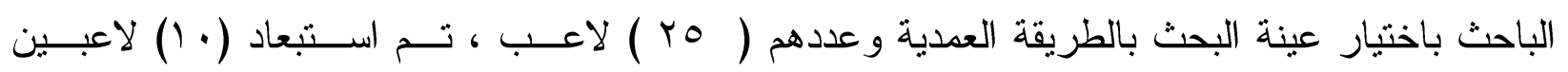
لاستخدامهم كعينة استطلاعية ، وبذلك اصبحت عينة البحث الاساسية (10) لاعب تم تطبيق تجربة البحث

\begin{tabular}{|c|c|c|c|c|c|}
\hline \multicolumn{6}{|c|}{ تصنيف عينة البحث } \\
\hline \multicolumn{2}{|c|}{ عينة البحث الاستطلاعية } & \multicolumn{2}{|c|}{ عينة البحث الأساسية } & \multicolumn{2}{|c|}{ عينة البحث الكلية } \\
\hline$\%$ & العدد & $\%$ & 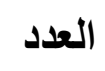 & $\%$ & العدد \\
\hline$\varepsilon \cdot \ldots$ & 1. & $7 . \ldots$ & 10 & $1 \ldots$ & ro \\
\hline
\end{tabular}




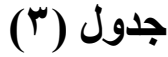

إعتدالية توزيع أفراد عينة البحث في الاختبارات البلنية قيد البحث

\begin{tabular}{|c|c|c|c|c|c|c|}
\hline الالتواء معامل & المعياري & الوسيط & المستوسط & والقياس & المتغير ات & م \\
\hline 0.81 & 0.37 & 5.95 & 6.05 & 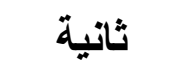 & عدو ·rمتر & 1 \\
\hline 1.25 & 1.03 & 7.93 & 8.36 & ثانية & عدو ·rمتر × همرات & $r$ \\
\hline $0.97-$ & 3.35 & 41.00 & 39.92 & عدل مرات & ضرب الكرة بالقدم والرأس لمدة & $r$ \\
\hline $0.76-$ & 5.72 & 173.00 & 171.56 & سم & الوثب العريض من الثبات & $\varepsilon$ \\
\hline 0.64 & 2.24 & 18.00 & 18.48 & عدل مرات & تمرير الكرة على حائط الصلد & 0 \\
\hline
\end{tabular}

يتضح من جدول (4 ) أن جميع قيم معاملات الالتو اء لأفر اد عينة البحث الكلية تراوحت بين ( 0.97

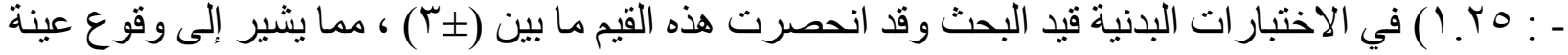
البحث الكلية داخل المنحنى الاعتداليي ، و هذا يذل على تجانس أفر اد العينة في هذه المتغيرات .

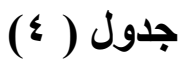

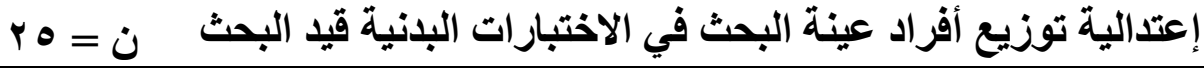

\begin{tabular}{|c|c|c|c|c|c|c|}
\hline الالتواء & المعياري & الوسيط & الحستبط & القياس & المتغيرات & م \\
\hline 0.81 & 0.37 & 5.95 & 6.05 & ثانية & عدو ·rمتر & 1 \\
\hline 1.25 & 1.03 & 7.93 & 8.36 & ثانية & عدو ·rمتر × همرات & r \\
\hline $0.97-$ & 3.35 & 41.00 & 39.92 & عدد مرات & ضرب الكرة بالقدم والرأس لمدة & $r$ \\
\hline $0.76-$ & 5.72 & 173.00 & 171.56 & 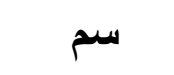 & الوثب العريض من الثبات & $\varepsilon$ \\
\hline 0.64 & 2.24 & 18.00 & 18.48 & عدد مرات & تمرير الكرة على حائط الصد & 0 \\
\hline
\end{tabular}


يتضح من جدول (4 ) أن جميع قيم معاملات الالتو اء لأفر اد عينة البحث الكلية تر اوحت بين ( 0.97

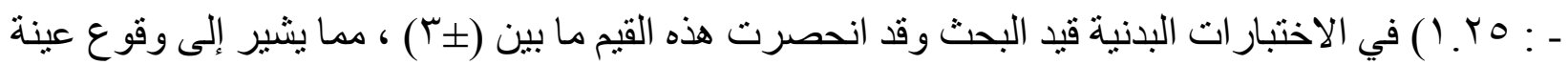
البحث الكلية داخل المنحنى الاعتداليب ، و هذا يدل على تجانس أفر اد العينة في هذه المتغيرات . r- إعتدالية عينة البحث في الأختبارات المهارية قيد البحث: قام الباحث بحساب معـامـل الالتواء بدلالة كل من المتوسط الحسابي و الوسبط و الانحر اف المعياري لعينة البحث في الأختبار ات المهاريـة قيد البحث (تمرير الكرة من الحركة خـلال مر امسى صغيرة وبالقدم

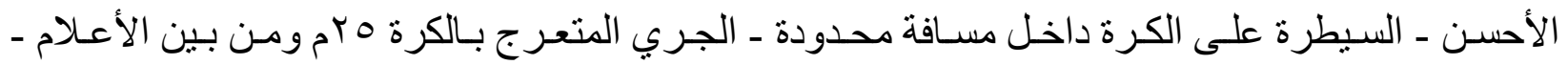
تصويب الكره إلي المرمي في جزء محدد) ، كما يتضح فيجدول() . جدول (0)

إعتدالية توزيع أفراد عينة البحث في الأختبارات

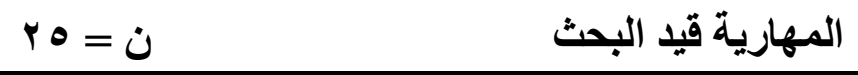

\begin{tabular}{|c|c|c|c|c|c|c|}
\hline الالتواء معامل & المعياري & الوسيط & الحتوسطي & القياس & المتغيرات & r \\
\hline $1.03-$ & 1.05 & 5.00 & 4.64 & درجة & تمرامى صغير الكرة من الحركة خلالقدم الأحسن & 1 \\
\hline 0.65 & 1.29 & 5.00 & 5.28 & درجة & السيطرة على الكرة داخل & $r$ \\
\hline $0.74-$ & 0.73 & 14.65 & 14.47 & ثانية & الجري المتعرج بالكرة بrم ومن & $\mu$ \\
\hline $0.91-$ & 1.32 & 7.00 & 6.6 & درجة & تصويب الكره إلي المرمي ـِ جزء & \{ \\
\hline
\end{tabular}

يتضح من جدول (5 ) أن جميع قيم معاملات الالتو اء لأفر اد عينة البحث الكلية تر اوحت بين ( 1.03

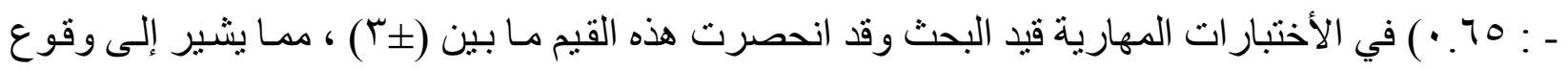
عينة البحث الكلية داخل المنحنى الاعتداليي ، وهذا بدل على تجانس أفراد العينة في هذه المتغيرات . 
r- إعتدالية عينة البحث في الأختبارات الخططية قيا البحث:

قام الباحث بحساب معـامـل الالتو اء بدلالة كل من المتوسط الحسابي و الوسبط و الانحر اف المعياري

لعينة البحث في الأختبار ات الخططية قيد البحث (قياس العمق في الهجوم - قياس الاتساع في الهجوم - قياس الجري الحر وتبادل المر اكز - قياس المتابعة في الهجوم) ، كما يتضح فيجدول() ) ل

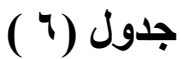

إعتدالية توزيع أفراد عينة البحث في (الإن

ro $=\dot{0}$

الأختبارات الخططية قيد البحث

\begin{tabular}{|c|c|c|c|c|c|c|}
\hline الالتواء معامل & المعياري & الوسيط & الحسابي & القياس & المتغيرات & م \\
\hline $0.84-$ & 0.43 & 4.00 & 3.88 & درجة & قياس العمق ـِ الهجوم & 1 \\
\hline 0.72 & 0.67 & 4.00 & 4.16 & درجة & قياس الاتساع بِ الهجوم & $r$ \\
\hline 1.08 & 0.78 & 4.00 & 4.28 & درجة & قياس الجري الحروتبادل المراكز & $r$ \\
\hline $0.91-$ & 0.92 & 5.00 & 4.72 & درجة & قياس المتابعة يِ الهجوم & $\varepsilon$ \\
\hline
\end{tabular}

يتضح من جدول (6 ) أن جميع قيم معاملات الالتو اء لأفر اد عينة البحث الكلية تراوحت بين (- 91.

:08: ( ) في الأختبار ات الخططية قيد البحث وقد انحصرت هذه القيم ما بين (بـ) ، مما يشير إلى وقوع عينة

البحث الكلية داخل المنحنى الاعتداليي ، و هذا يدل على تجانس أفر اد العينة في هذه المتغير ات ـ

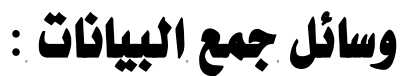

استخدم الباحث فى جمع البيانات و المعلومات المتعلقة بهذالبحث الادوات و الأجززة التالية:

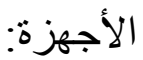

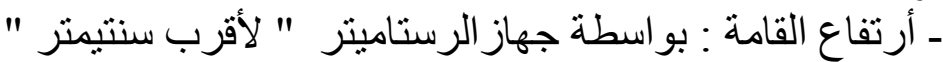

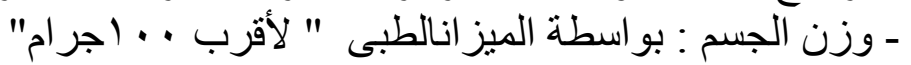

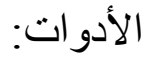

ـ استمار ات تسجيل البيانات.

- ملعب كرة قدم.

- كر ات قدم.

ـ ـ اقماع بلاستلك.

ـ ـ اطباق بلاستك.

ـ مقاعد سويدية.

ـ شريط قياس بالسم. 
ـ ساعات إيقاف ( • / ثانية )

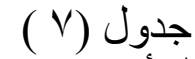

\section{الاختبارات البدنية المختقارة:}

\begin{tabular}{|c|c|c|c|}
\hline النسبة المئوبية & عدد ار اء المو أْفين & الاختبار & م \\
\hline$\% 1 \cdots$ & $1 \cdot$ & عدو · مثتر & 1 \\
\hline$\% 1 \cdots$ & $1 \cdot$ & عدو ، سمتر × مدرات & r \\
\hline$\% 1 \cdots$ & 1. & ضرب الكرة بالقدم و الر أس لمدة دقيقة & r \\
\hline$\% 9$. & 9 & الوثب العريض من الثبات & $\varepsilon$ \\
\hline$\% 9$. & 9 & تمرير الكرة على حائط الصد خلال • ب ثانية & 0 \\
\hline
\end{tabular}

وبذللك استقر الباحث على الاختبار ات البدنية التالية:

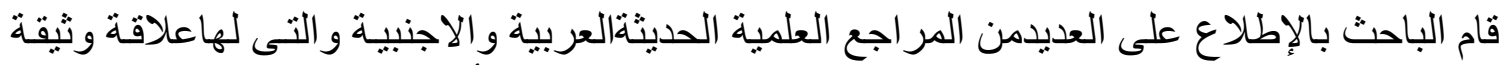

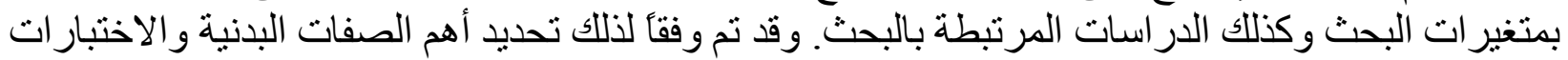

$$
\text { - - }
$$

- اختبار ضرب الكرة بالقدم و الر أس لمدة دقيقة.

$$
\text { - - اختبار الوثب العريض من الثبات. }
$$

- اختبار تمرير الكرة على حائط الصد خلال • ب ثانية.

\begin{tabular}{|c|c|c|c|}
\hline المئوبة النسة & المو افقين إئ & الاختبار & s \\
\hline$\% 1 \cdots$ & $1 \cdot$ & تمرير الكرة من الحركة خلال مر امى صغيرة وبالقدم الأحسن & 1 \\
\hline$\% 1 \cdots$ & $1 \cdot$ & السيطرة على الكرة داخل مسافة محدودة & r \\
\hline$\% 1 \cdots$ & $1 \cdot$ & الجري المتعرج بالكرة ه بم ومن بين الأعلام & r \\
\hline$\% 1 \cdots$ & $1 \cdot$ & تصويب الكره إلي المرمي في جزء محدد & $\varepsilon$ \\
\hline
\end{tabular}

\section{الاختبارات المهارية :}

\section{جدول (^)}




$$
\begin{aligned}
& \text { - اختبار الجري المتعرج بالكرة هب ومن بين الأعلام. } \\
& \text { - اختبار السيطرة على الكرة داخل مسافة محدودة. } \\
& \text { - اختبار تصويب الكره إلي المرمي في جزء محدد. }
\end{aligned}
$$

استخدم الباحث مقياس الأداء الجمـاعى (لقياس التحركات) الخططية للاعبين وقد أسفرت عن ع

الاختبارات الخمطhية :

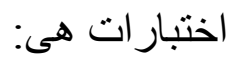

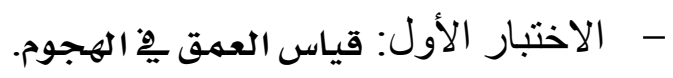
- - الاختبار الثانى: قياس الاتساع ٌِِ الهجوم.

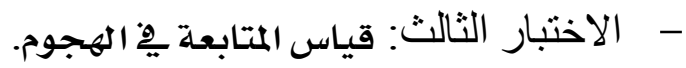

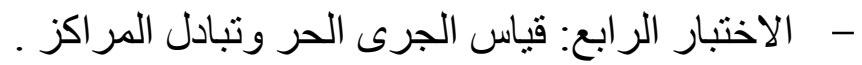

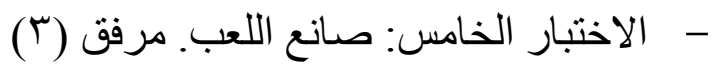

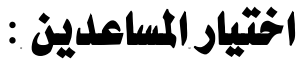

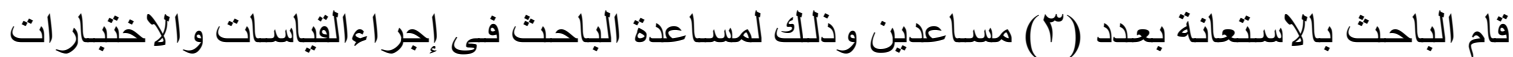

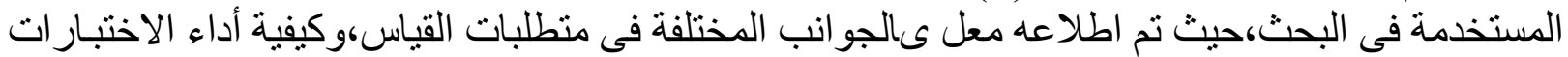

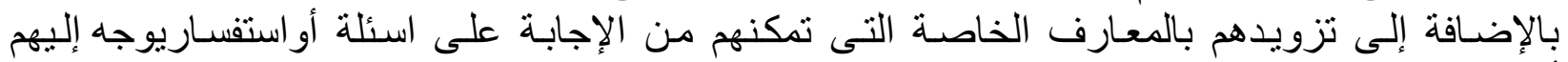

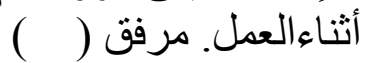

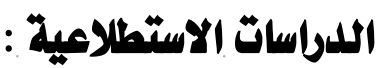

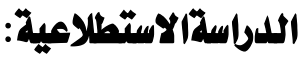

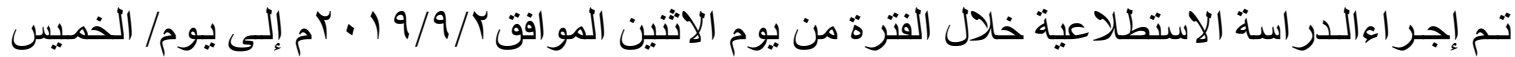
19/9/0 • ب م وذلك لإيجاد المعاملات العلمية (الصدق_الثبات) للاختبار ات قيد البحث.

$$
\begin{aligned}
& \text { المعاملات العلمية للاختبارات قيد البحث . } \\
& \text { اولا : إيجاد معامل الصدق . }
\end{aligned}
$$

قام الباحث بإيجاد معامل صدق الأختبار ات بتطبيق صدق التمايز على مجمو عتين أحداهما ذات

مستوى مرتفع (المجمو عة المميزة) و عددهم (• (1) ناثـئينتحت 9 (سنة و المجمو عـة الأخرى (غير المميزة)

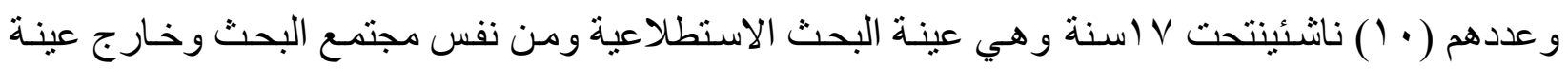
البحث الأساسية، وجدول () يوضح ذللك . 


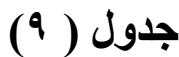

دلالة الفروق بين المجموعتين المميزة وغير المميزة في الاختبارات البدنية

والاختبارات المهارية والاختبارات الخططية قيل البحث

\begin{tabular}{|c|c|c|c|c|c|c|c|}
\hline \multirow[b]{2}{*}{ قالمسمة (ت) } & \multicolumn{2}{|c|}{ المجموعة غير المميزة } & \multicolumn{2}{|c|}{ المجموعة المميزة } & \multirow{2}{*}{ وحدة القياس } & \multirow[b]{2}{*}{ الاختبار ات } & \multirow[b]{2}{*}{ p } \\
\hline & المعياري & الحستوسط & المعياري & الحستبي & & & \\
\hline 6.34 & 0.46 & 6.08 & 0.25 & 5.03 & ثانية & عدو · بامتر & 1 \\
\hline 6.76 & 0.78 & 8.23 & 0.34 & 6.41 & ثانية & عدو · "امتر × همرات & r \\
\hline 7.15 & 3.41 & 40.40 & 3.41 & 51.3 & مرات عد & ضرب الكرة بالقدم والرأس لمدة & $\Gamma$ \\
\hline 5.93 & 5.97 & 172.15 & 6.09 & 188.15 & سم & الوثب العريض من الثبات & $\xi$ \\
\hline 7.27 & 1.95 & 18.10 & 2.67 & 25.70 & 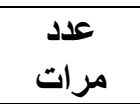 & تمرير الكرة على حائط الصد خلال & 0 \\
\hline 5.62 & 1.17 & 4.80 & 0.78 & 7.30 & ل درجة & مرامى صغيرة الكرة من القركة الأحسن & 7 \\
\hline 6.13 & 1.04 & 5.10 & 0.67 & 7.50 & 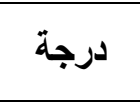 & السيطرة على الكرة داخل مسافة & V \\
\hline 7.36 & 0.68 & 14.47 & 0.31 & 12.73 & ثانية & الجري المتعرج بالكرة ه ب م ومن & $\wedge$ \\
\hline 6.05 & 1.19 & 6.30 & 0.85 & 9.10 & درجة & تصويب الكره إلي المرمي في جزء & 9 \\
\hline 6.87 & 0.45 & 4.00 & 0.64 & 5.70 & درجة & قياس العمق في الهجوم & $1 \cdot$ \\
\hline 6.30 & 0.78 & 4.30 & 0.85 & 6.60 & 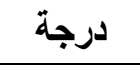 & قياس الاتساع في الهجوم & 11 \\
\hline 6.19 & 0.81 & 4.50 & 0.92 & 6.90 & درجة & قياس الجري الحر وتبادل المراكز & IT \\
\hline 5.41 & 0.93 & 5.10 & 0.97 & 7.40 & درجة & قياس المتابعة في الهجوم & 14 \\
\hline
\end{tabular}

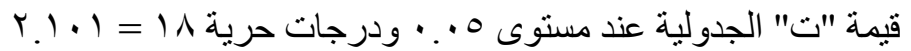

يتضح من جدول (9) وجود فروق ذات دلالة إحصائية في بين المجمو عة المميزة و المجموعة غير

المميزة لصالح المجمو عة المميزة في جميع الاختبار ات البدنية والاختبار ات المهارية و الاختبار ات الخططية

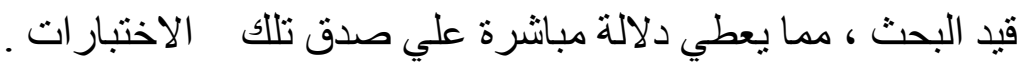

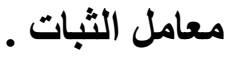

قام الباحث بحساب ثبات الاختبار ات باستخدام طريقة تطبيق الاختبار اتمن يوم الاثثين / 19/9 ـ rم

ثم إعادة تطبيقها مرة أخرى على عينـة الدر اسـة الاستطلاعية وعددهم (• ( ) ناثشئين تحت V V اسنة، بفاصل زمني ثلاثة أيام (rVاساعة) يوم الخميس 19/9/0 ـ بم بين نتائج التطبيق الأول و التطبيق الثاني ، كما يتضح

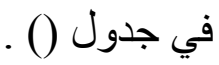




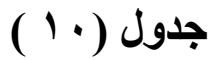

معامل الأرتباط بين التطبيق الأول والثاني للعينة الاستطلاعية في الأختبارات

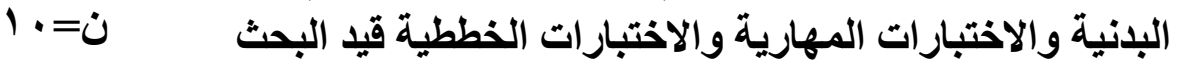

\begin{tabular}{|c|c|c|c|c|c|c|c|}
\hline \multirow[b]{2}{*}{ الميمة (ر) } & \multicolumn{2}{|c|}{ التطبيق الثاني } & \multicolumn{2}{|c|}{ التطبيق الأول } & \multirow{2}{*}{ والقدة } & \multirow[b]{2}{*}{ الاختبار ات } & \multirow[b]{2}{*}{ b } \\
\hline & المعياري & الحسابي & الالاتحرافي & الحسابي & & & \\
\hline 0.91 & 0.43 & 6.04 & 0.46 & 6.08 & ثانية & عدو · بمتر & 1 \\
\hline 0.90 & 0.65 & 7.98 & 0.78 & 8.23 & ثانية & عدو · بامتر × ممرات & r \\
\hline 0.92 & 3.80 & 40.9 & 3.41 & 40.40 & مرات & ضرب الكرة بالقدم والرأس لمدة & $r$ \\
\hline 0.89 & 6.56 & 171.55 & 5.97 & 172.15 & سم & الوثب العريض من الثبات & $\varepsilon$ \\
\hline 0.88 & 2.14 & 18.30 & 1.95 & 18.10 & 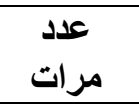 & تمرير الكرة على حانية الصد & 0 \\
\hline 0.86 & 1.21 & 4.90 & 1.17 & 4.80 & درجة & تمرامى صغيرة وبالقام الأحسن & 7 \\
\hline 0.87 & 1.08 & 5.20 & 1.04 & 5.10 & درجة & السيطرة على الكرة داخل مسافة & $\mathrm{V}$ \\
\hline 0.89 & 0.65 & 14.36 & 0.68 & 14.47 & ثانية & الجري المتعرج بالكرة ه ب م ومن & $\wedge$ \\
\hline 0.90 & 1.28 & 6.40 & 1.19 & 6.30 & درجة & تصويب الكره إلى المرمي في & 9 \\
\hline 0.84 & 0.53 & 4.10 & 0.45 & 4.00 & درجة & قياس العمق في الهجوم & $1 \cdot$ \\
\hline 0.85 & 1.02 & 4.40 & 0.78 & 4.30 & درجة & قياس الاتساع في الهجوم & 11 \\
\hline 0.87 & 1.05 & 4.70 & 0.81 & 4.50 & درجة & قياس الجري الحر وتبادل المراكز & IT \\
\hline 0.86 & 1.07 & 5.20 & 0.93 & 5.10 & درجة & قياس المتابعة في الهجوم & 14 \\
\hline
\end{tabular}

قيمة "ر" الجدولية عند مستوى 0 . . ودرجات حرية $9=$

يتضح من جدول (• (1) وجود علاقة إرتباطية ذات دلالتة إحصائية عند مستوى معنويـة ه . . • بين التطبيق الأول و إعادة التطبيق في جميع الاختبار ات البدنية و الاختبار ات المهارية والاختبار ات الخططية قيد البحث ، مما يعطي دلالة مباشرة علي ثبات هذه الاختبار ات .

البرئامج التلدريبي المقترح :

قام الباحث بوضع البرنامج التدريبى المقترح من خلال الإطلاع على المر اجع العلمية المتخصصة

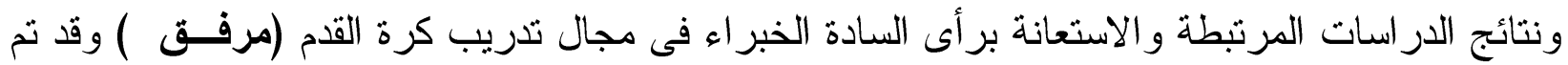
ذللك وفقا للخطو ات التالية: الئ 


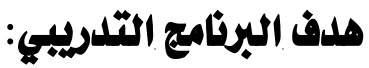

يهدف البرنامج التنرييى المقترح الى تطوير بعض جو انب الاداء الفنى لنانشئ كرة القدم .

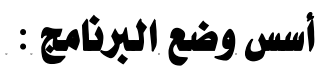

انطلاقامن أهداف البحث وخصائص عينة البحث و الاستفادة بآراء الخبر اءكتم وضع الأسس التالية

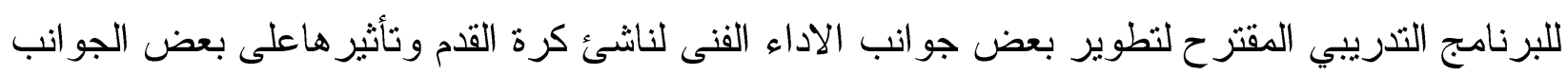

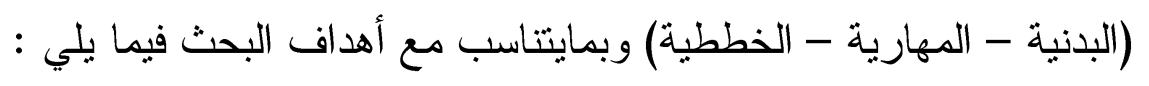

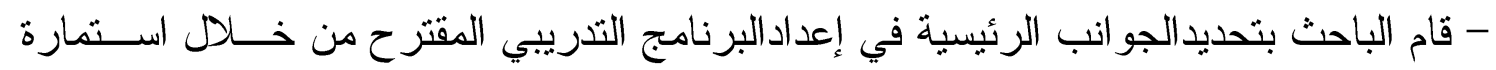

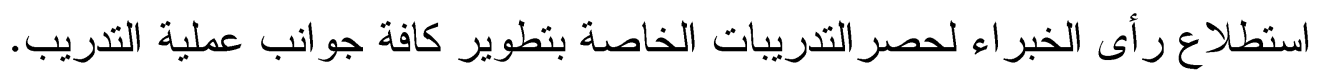

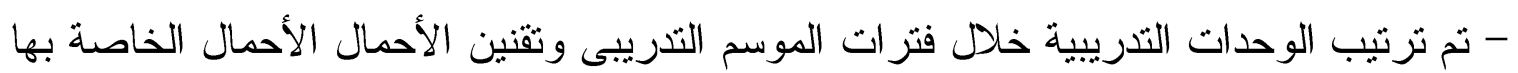

$$
\text { والمشتملة على (الثدة - الحجم - النكرار). }
$$

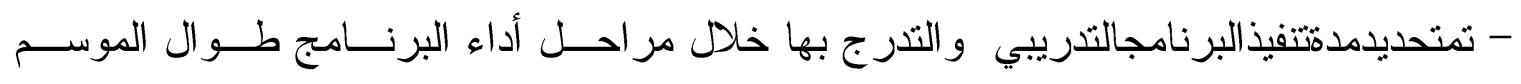

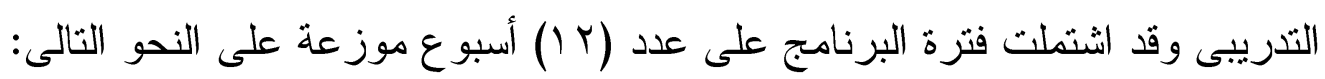

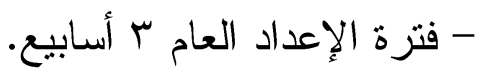

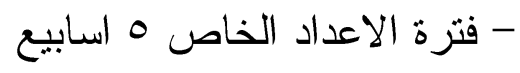

- فترة الاعداد للمنافسات ع أسابيع.

- تم تحديدعدالوحدات التنريبية اليوميةخلال الأسبوع على النحو التالى: وحدات

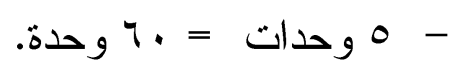

\section{تشكيل العمل التلدريبى للبرنامج التدريب:}

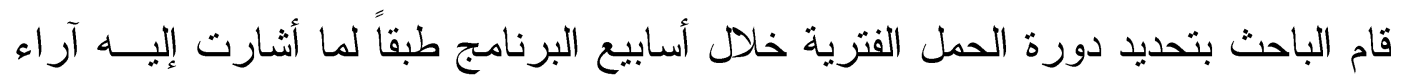
الخبراء باستخدام أسلوب r : : أبي أسبوع للاحاحة أو الاستشفاء.

\section{توزيع العمل التدريبى خلال وحدة التدريب اليومية:}

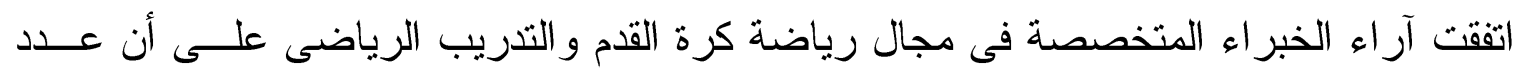

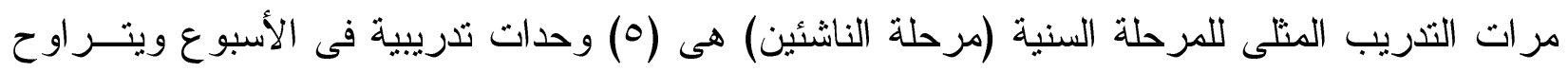

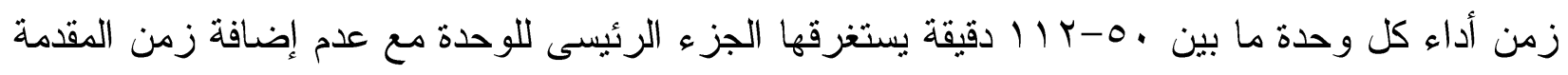




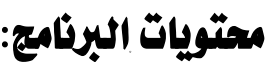

بناءُ على ما استقر عليه الباحث من خلال استطلاع رأى الخبراء للعناصر المؤثرة على تطــــير الاداء الفنى من (المستوى البذنى و الدهارى و الخططى) واشتملت مكونات البرنامج التنريبى على الفترات

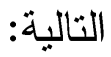

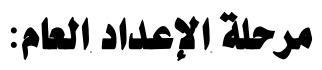

وقد اشتملت هذه المرحلة على التنريبات الهو ائية واللاهو ائية لدور ها الهام فى رفع مستوى اللياقة

البدنية و الوظيفية للاعبين.

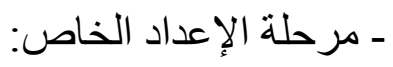

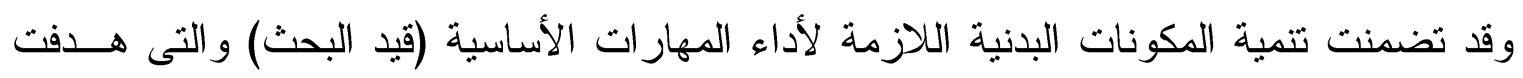

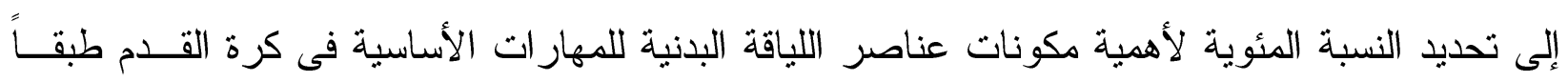

$$
\begin{aligned}
& \text { لاسنطلاع آراء الخبر اء. وقد تنثلت فى : لإنى } \\
& \text { تحمل الأداء: والذى اشتمل على نحملات (السر عة والقوة). } \\
& \text { القوة العضلية } \\
& \text { الرشاقة }
\end{aligned}
$$

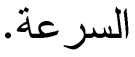

$$
\begin{aligned}
& \text { المرونـــــة. }
\end{aligned}
$$

وقد احتوى هذا الجزء خلال البرنامج التدريبى على المهارات الأساسـيـية والتــدريبات المركبــة

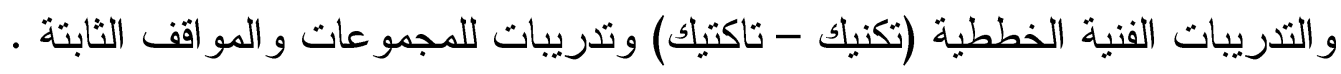

مرحلة الاعداد للنيافسات:

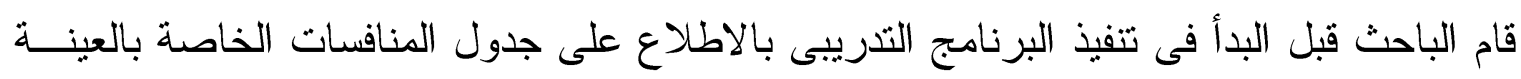

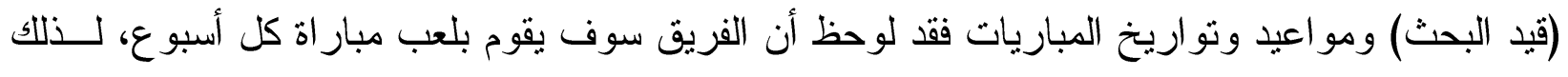

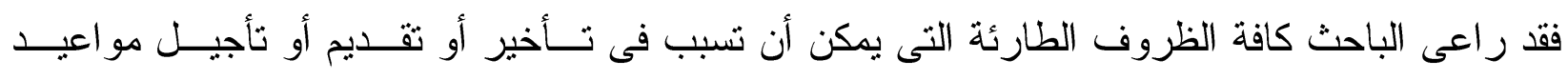

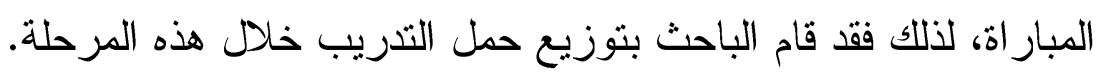

\section{التوزيع الزمفى لمحتويات البرنامج:}

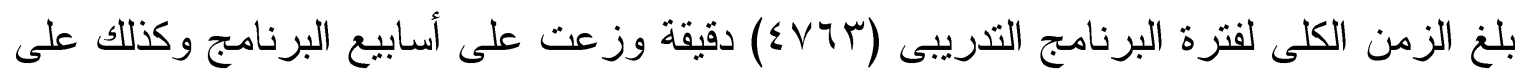

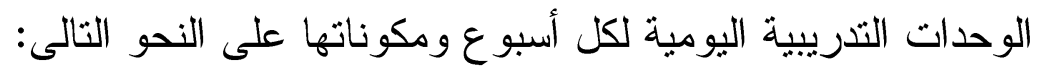




\section{التوزيع الزمنى للوحدات اليومية خلال أسابيع البرنامج :}

بناءً على ما تم اتفاق الخبر اء عليه لتحقيق تطوير الاداء الفنى لعناصــرها ها (البدنيــة و المهاريـــة و الخططية) فقد تم تحديد أزمنة الوحدة التثريبية اليومية. فقد قام الباحث بتوزيع زمن الوحدات التدريبيــة طبقاً للهدف العام من حمل التدريب لكل أسبوع ولكل وحدة يومية تدريبية. مكوذات الوحلدة التدريبية اليومية:

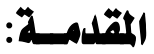

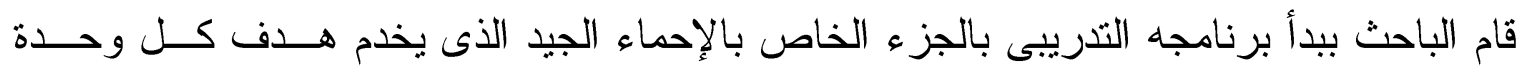
تدريبية يومية ، وقد بلغت مدته من (10) دقيقة بهدف تتبيه الجهاز العصبى المركزى و الجهاز الحركى بـى باهي وزيادة نشاط الجهاز التتفسى.

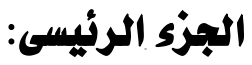

تم فى هذا الجزء من الوحد التـريبية من البرنامج و التىى تم اختيار ها لتحقيق هدف كــل مرحلـــة

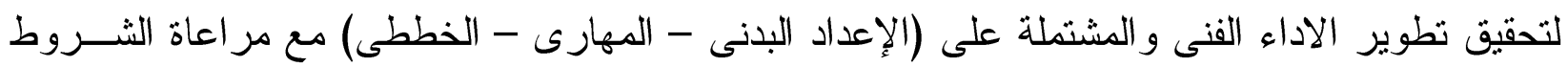
الموضوعة لكل تمرين من حيث الثدة وعدد مرات التكرار و عدد المجموعات وفترات الراحة لكل تمرين ملين الرداه و أسلوب ومو اصفات التمرين.

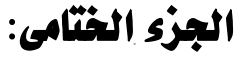
وقد تحدد هذا الجزء من الوحدة التدريبية للبرنامج لتحقيق التهدئة و الاستشفاء من التدريبات لعودة الجسم لحالته الطبيعية قبل بدأ الوحدة التّريبية. و الجدول التالى يوضح بعد جمع البيانات وتسجيل القياسـات المختلفة للمتغيرات التي استخدمت في هذا البحث ،تم إجر اء المعالجات الإحصائية المناسبة لتحقيق الأهـداف

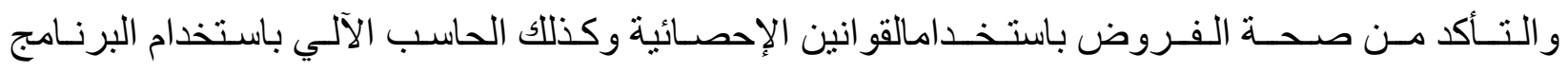

$$
\text { الإحصائي" "SPSS" وتم حساب ما يلي: }
$$

Mean .

Median .

Standard Deviation .

Skewness .

Paired Samples T Test .

Correlation (person) . Analysis of variance .

L.S.D .

$$
\text { المنوسط الحسابي. }
$$
الوسيط.

Percentage of Progress .

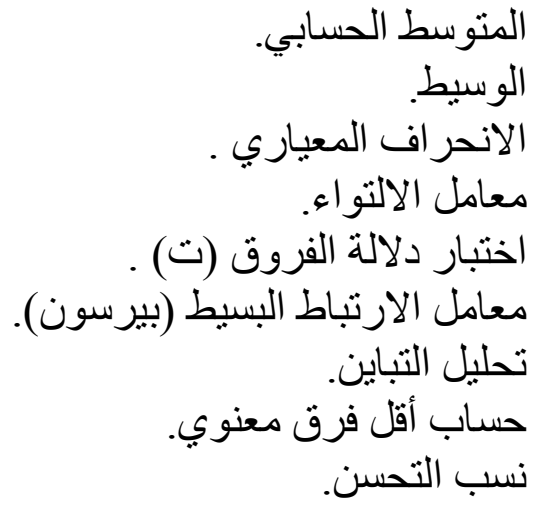


عرض ومناقشة النتائج . عرض النتائج . عرض نتائج الفرض الأول:

جدول (1) (1)

تحليل التباين بين قياسات البحث الثثلاثة (قبلي - تتبعي - بعدى)

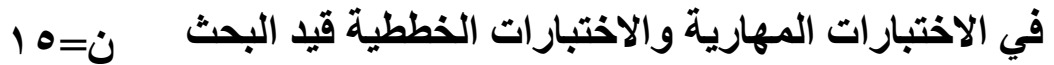

\begin{tabular}{|c|c|c|c|c|c|c|c|}
\hline الدلالة & التباين & متوسط المربعات & الحرية & المربعات & |مصدر التباين & المتغيرات & b \\
\hline \multirow{2}{*}{ دالة } & \multirow{2}{*}{27.21} & 28.16 & 2 & 56.31 & بين القياسات & \multirow{2}{*}{ تمرير الكرة من الحركة خلال } & \multirow{2}{*}{1} \\
\hline & & 1.03 & 42 & 43.47 & |داخل القياسـات & & \\
\hline \multirow{2}{*}{ دالة ل } & \multirow{2}{*}{22.53} & 17.16 & 2 & 34.36 & بين القياسات & \multirow{2}{*}{ السيطرة على الكرة داخل مسافة } & \multirow{2}{*}{$r$} \\
\hline & & 0.76 & 42 & 32.00 & |داخل القياسات & & \\
\hline \multirow{2}{*}{ دالة ل } & \multirow{2}{*}{25.87} & 14.39 & 2 & 28.79 & بين القياسات & \multirow{2}{*}{ الجري المتعرج بالكرة هب م ومن } & \multirow{2}{*}{ r } \\
\hline & & 0.52 & 42 & 23.36 & |داخل القياسات & & \\
\hline \multirow{2}{*}{ دالة ل } & \multirow{2}{*}{20.74} & 19.35 & 2 & 38.71 & بين القياسات & \multirow{2}{*}{ تصويب الكره إلي المرمي في } & \multirow{2}{*}{4} \\
\hline & & 0.93 & 42 & 39.20 & |داخل القياسات & & \\
\hline \multirow{2}{*}{ 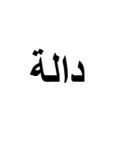 } & \multirow{2}{*}{39.25} & 11.47 & 2 & 22.93 & | بين القياسات & \multirow{2}{*}{ قياس العمق في الهجوم } & \multirow{2}{*}{0} \\
\hline & & 0.29 & 42 & 12.27 & |داخل القياسات & & \\
\hline \multirow{2}{*}{ دالة ل } & \multirow{2}{*}{31.39} & 13.16 & 2 & 26.31 & بين القياسات & \multirow{2}{*}{ قياس الاتساع في الهجوم } & \multirow{2}{*}{9} \\
\hline & & 0.41 & 42 & 17.60 & |داخل القياسات & & \\
\hline \multirow{2}{*}{ 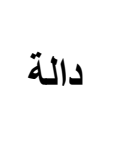 } & \multirow{2}{*}{34.26} & 19.45 & 2 & 38.93 & بين القياسات & \multirow{2}{*}{ قياس الجري الحر وتبادل } & \multirow{2}{*}{ V } \\
\hline & & 0.56 & 42 & 23.87 & |داخل القياسات & & \\
\hline \multirow{2}{*}{ 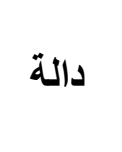 } & \multirow{2}{*}{32.24} & 21.69 & 2 & 43.38 & بين القياسات & \multirow{2}{*}{ قياس المتابعة في الهجوم } & \multirow{2}{*}{$\wedge$} \\
\hline & & 0.67 & 42 & 28.27 & |داخل القياسات & & \\
\hline
\end{tabular}


يتضح من جدول ( (1) وجود فروق دالة إحصائيًا بين قياسات البحث الثثلاثة (قبلي - تتبعي - بعدى) في جميع الاختبارات المهارية والاختبارات الخططية قيد البحث ، وسوف يقوم الباحث بإجراء اختبار (L.S.D)

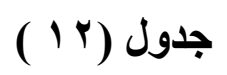

دلالة الفروق بين قياسات البحث الثلاثة (قبلي - تتبعي - بعدى)

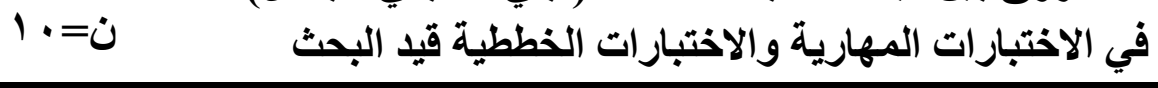

\begin{tabular}{|c|c|c|c|c|c|c|}
\hline \multirow{2}{*}{ 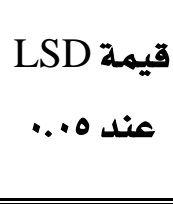 } & \multicolumn{2}{|c|}{ فروق المتوسطات } & \multirow{2}{*}{ الحسابي } & \multirow[b]{2}{*}{ القياسات } & \multirow[b]{2}{*}{ المتغيرات } & \multirow[b]{2}{*}{ r } \\
\hline & البعدي & التتبعي & & & & \\
\hline \multirow{3}{*}{0.75} & 2.73 & 1.20 & 4.47 & القياس القبلي & \multirow{3}{*}{ مرامى صغيرة وبالقدم الأحسن } & \multirow{3}{*}{1} \\
\hline & 1.53 & & 5.67 & القياس التتبعي & & \\
\hline & & & 7.20 & القياس البعدي & & \\
\hline \multirow{3}{*}{0.64} & 2.14 & 0.94 & 5.33 & القياس القبلي & \multirow{3}{*}{ السيطرة على الكرة داخل مسافة } & \multirow{3}{*}{2} \\
\hline & 1.20 & & 6.27 & القياس التتبعي & & \\
\hline & & & 7.47 & القياس البعدي & & \\
\hline \multirow{3}{*}{0.53} & 1.96 & 0.92 & 14.59 & القياس القبلي & \multirow{3}{*}{ 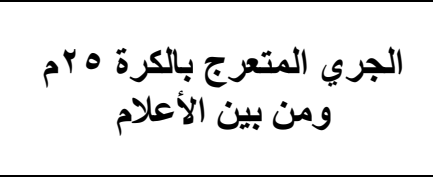 } & \multirow{3}{*}{ r } \\
\hline & 1.04 & & 13.67 & القياس التتبعي & & \\
\hline & & & 12.63 & القياس البعدي & & \\
\hline \multirow{3}{*}{0.71} & 2.26 & 1.06 & 6.87 & القياس القبلي & \multirow{3}{*}{ تصويب الكره إلي المرمي في } & \multirow{3}{*}{$\varepsilon$} \\
\hline & 1.20 & & 7.93 & القياس التتبعي & & \\
\hline & & & 9.13 & القياس البعدي & & \\
\hline \multirow{3}{*}{0.40} & 1.74 & 0.67 & 3.73 & القياس القبلي & \multirow{3}{*}{ قياس العقى في الهجوم } & \multirow{3}{*}{5} \\
\hline & 1.07 & & 4.40 & القياس التتبعي & & \\
\hline & & & 5.47 & القياس البعدي & & \\
\hline \multirow{3}{*}{0.47} & 1.86 & 0.80 & 4.07 & القياس القبلي & \multirow{3}{*}{ قياس الاتساع في الهجوم } & \multirow{3}{*}{6} \\
\hline & 1.06 & & 4.87 & القياس التتبعي & & \\
\hline & & & 5.93 & القياس البعدي & & \\
\hline \multirow{3}{*}{0.55} & 2.27 & 0.93 & 4.20 & القياس القبلي & \multirow{3}{*}{ قياس الجري الحر وتبادل } & \multirow{3}{*}{ v } \\
\hline & 1.34 & & 5.13 & القياس التتبعي & & \\
\hline & & & 6.47 & القياس البعدي & & \\
\hline \multirow{3}{*}{0.60} & 2.40 & 1.07 & 4.93 & القياس القبلي & \multirow{3}{*}{ قياس المتابعة في الهجوم } & \multirow{3}{*}{8} \\
\hline & 1.33 & & 6.00 & القياس التتبعي & & \\
\hline & & & 7.33 & القياس البعدي & & \\
\hline
\end{tabular}


يتضح من جدول (r) وجود فروق دالة إحصائياً بين القياس البعدي وكلا من القياسين التتبعي

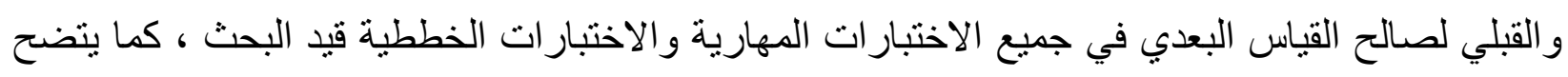

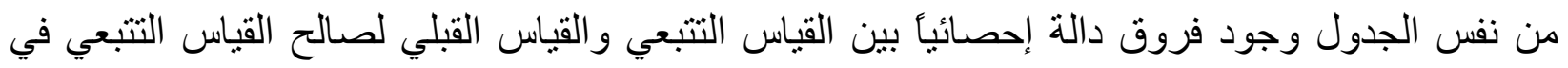

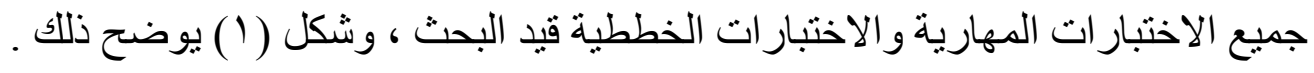

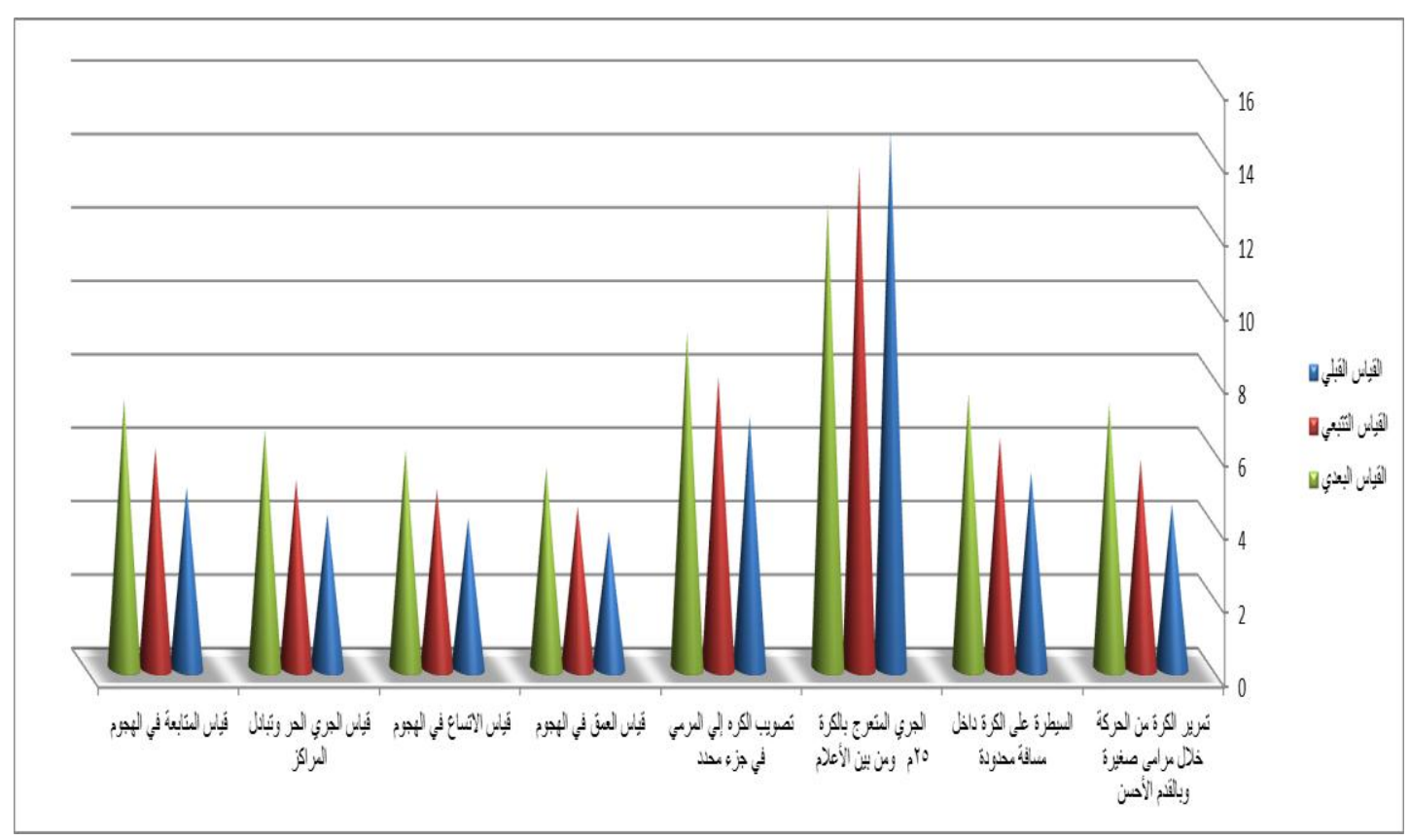

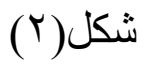

دلالة الفروق بين قياسات البحث الثلاثة (قبلي-تنبعي-بعدى) في الاختبار ات المهارية والاختبار اتلات الخططية قيد البحث 


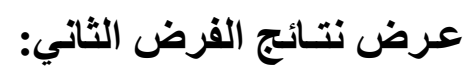

جدول (1) (I)

نسب التحسن بين قياسات البحث الثثلاثة (قبلي - تتبعي - بعدى)

في الاختبارات المهارية والاختبارات الخططية قيد البحث

\begin{tabular}{|c|c|c|c|c|c|}
\hline \multicolumn{2}{|c|}{ ن نسب التحسن ٪ } & \multirow{2}{*}{ الحسابي } & \multirow[b]{2}{*}{ القياسات } & \multirow[b]{2}{*}{ المتغيرات } & \multirow[b]{2}{*}{ b } \\
\hline البعدي & القياس التتبعي & & & & \\
\hline 61.07 & 26.85 & 4.47 & القياس القبلي & \multirow{3}{*}{ تمر تمىير صغيرة مبن الحقدم الأحسلا } & \multirow{3}{*}{1} \\
\hline \multirow[t]{2}{*}{26.98} & & 5.67 & القياس التتبعي & & \\
\hline & & 7.20 & القياس البعدي & & \\
\hline 40.15 & 17.64 & 5.33 & القياس القبلي & \multirow{3}{*}{ السيطرة على الكرة داخل مسافة } & \multirow{3}{*}{ r } \\
\hline \multirow[t]{2}{*}{19.14} & & 6.27 & القياس التتبعي & & \\
\hline & & 7.47 & القياس البعدي & & \\
\hline 13.43 & 6.31 & 14.59 & القياس القبلي & \multirow{3}{*}{ الجري المتعرج بالكرة هبم ومن } & \multirow{3}{*}{$r$} \\
\hline \multirow[t]{2}{*}{7.61} & & 13.67 & القيّاس التتبعي & & \\
\hline & & 12.63 & القياس البعدي & & \\
\hline 32.90 & 15.43 & 6.87 & القياس القبلي & \multirow{3}{*}{ تصويب جزءه محضد المرمي في } & \multirow{3}{*}{$\varepsilon$} \\
\hline \multirow[t]{2}{*}{15.13} & & 7.93 & القياس التتبعي & & \\
\hline & & 9.13 & القياس البعدي & & \\
\hline 46.65 & 17.96 & 3.73 & القياس القبلي & \multirow{3}{*}{ قياس العمق في الهجوم } & \multirow{3}{*}{5} \\
\hline \multirow[t]{2}{*}{24.32} & & 4.40 & القياس التتبعي & & \\
\hline & & 5.47 & القياس البعدي & & \\
\hline 45.70 & 19.66 & 4.07 & القياس القبلي & \multirow{3}{*}{ قياس الاتساع في الهجوم } & \multirow{3}{*}{6} \\
\hline \multirow[t]{2}{*}{21.77} & & 4.87 & القياس التتبعي & & \\
\hline & & 5.93 & القياس البعدي & & \\
\hline 54.05 & 22.14 & 4.20 & القياس القبلي & \multirow{3}{*}{ قياس الجري الحر وتبادل المراكز } & \multirow{3}{*}{$\mathrm{v}$} \\
\hline \multirow[t]{2}{*}{26.12} & & 5.13 & القياس التتبعي & & \\
\hline & & 6.47 & القياس البعدي & & \\
\hline 48.68 & 21.70 & 4.93 & القياس القبلي & \multirow{3}{*}{ قياس المتابعة في الهجوم } & \multirow{3}{*}{$\wedge$} \\
\hline \multirow[t]{2}{*}{22.17} & & 6.00 & القيّاس التبتبعي & & \\
\hline & & 7.33 & القياس البعدي & & \\
\hline
\end{tabular}


الحركة خلال مر امى صغيرة وبالقدم الأحسن بنسبة مقدارها V • ـ آ\% , تليها قياس الجري الحر وتبادل المر اكز بنسبة مقدار ها ه . ـ ٪\% , بينمـا كانت أقل نسبة للتغير بين القياسين القبلي و البعدي في الجري

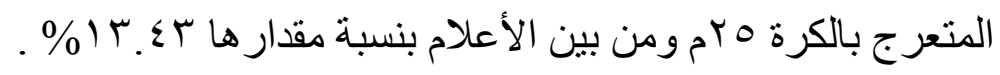

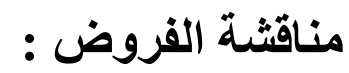

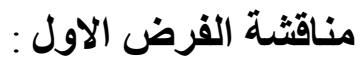

دلالة الفروق بين قياسات البحث الثلاثة (قبلي - تتبعي -بعدى) في الاختبار ات المهارية و الاختبار ات

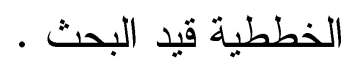
حيث تثير نتائج الدراسة فى الجدول رقم () إلى وجود فروق ذات دلالة إحصائية بين كل من درجات قبلي -تتبعي - بعدى لمجموعة البحث التجريبية فى جميع المتغيرات البدنية والمنمثلة فى ( السرعة ، تحمل السر عة ، القوة المميزه بالسر عة ،تحمل أداء ، سر عة اداء ) . وتتفق هذه النتائج مع دراسة كلا من ( محمد محمد مختار الزغبى ) (1990 ) ( محمد على محمود ) ( ) ( )

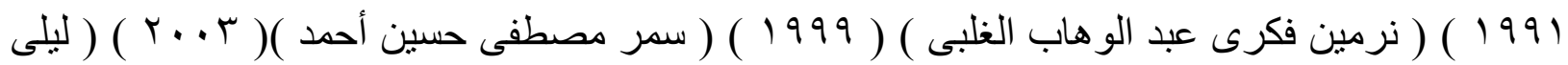

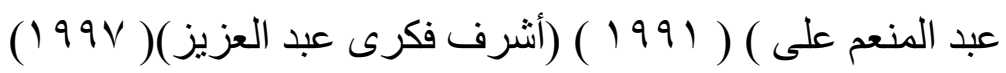

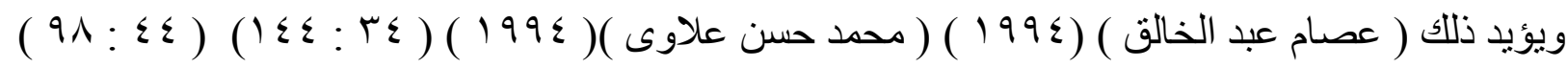

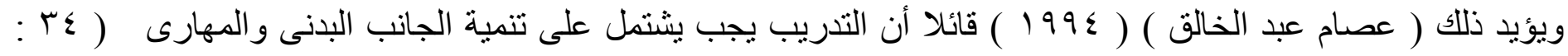
$(177$

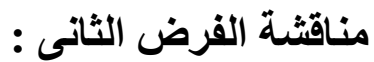

توجد فروق ذات دلالة إحصائية بين القياس القبلي و القياس البعدي لمستوى بعض جو انب الاداء الخططي لن انشئي كرة القدم.

حيث تثير نتائج الدر اسة فى الجدول رقم ( T I ) ) إلى وجود فروق ذات دلالة احصائية بين كل من درجات مجموعتى البحث المجمو عة الضابطة والمجمو عة التجريبية فى جميع الجو انب الخططى ولصالح المجموعة التجريبية .

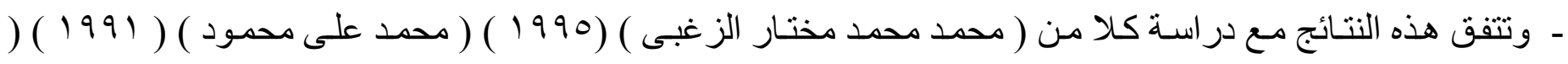

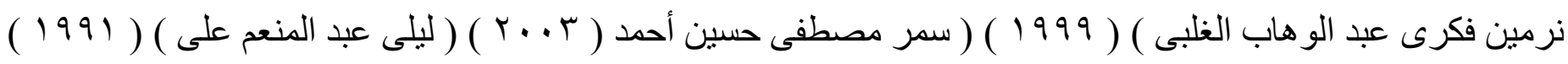

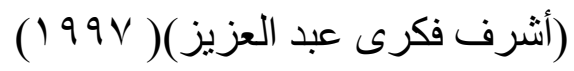


الإستخلاصات والتوصيات.

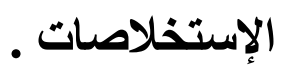

في ضوء أهداف البحث وفروضه وفي حدود عينة البحث وخصائصها ، ووفقاً إلى مـا أشـارت إليه

نتائج التحليل الإحصائي، أمكن للباحث التوصل إلى الاستخلاصات التالية :

استخدام البرنامج التعليمي باستخدام التدريب الضـاغط أظهر تأثنير آ إيجابياً على تدريب

بعض المهار ات الاساسية فى كرة القدم حيث توجد فروق دالة إحصـائية بين منوسطي

القياسين القبلي و البعدى للمجموعة التجريبية لصالح القياس البعدي.

• أظهرت فروق نسب التحسن بين القياس القبلى و البعدى للمجمو عة التجريبية في تدريب

بعض المهار ات الاساسية فى كرة القدم التي استخدمت البرنـامج التدريبى باستخدام

$$
\text { التدريب الضاغط. }
$$

اجر اء در اسات مشابهة على اللاعبين باستخدام المهار ات البدنية و الخططية و المهاريـة فى كرة القدم

و الالعاب الجماعية الاخرى.

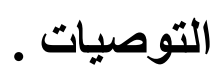

في ضوء النتائج و الإستخلاصات التي نم التوصل إليها يوصي الباحث بما يلي :

• تطبيق التدريبى باستخدام التدريب الضاغطفي تدريب بعض المهار ات الاساسية فى كرة

القدم فى المر احل السنية المختلفة .

• ضـرورة استخدام الوسـائل التدريبيـة الحديثة المناسبة و التـى تسـاعد فـى سـر عة تـدريب

و إتقان المهار ات الاساسية فى كرة القدم • 


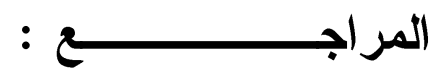

ا. أمر الله أحمد البساطي: دراسة تحليلية لأنواع الأداعات الحركية المركبة (المندمجة) في بعض

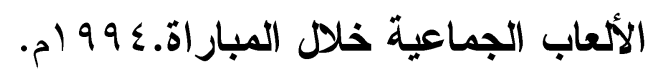
r. أمر الله البساطي :الإعداد البدني في كرة القدم ( تخطيط - تدريب - قياس )، دار الجامعة

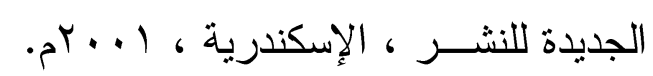

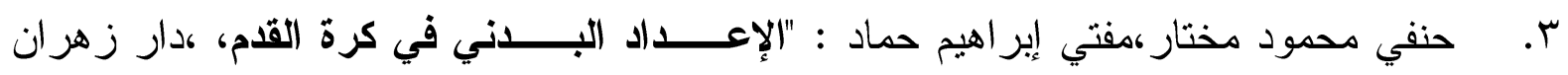

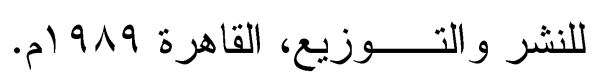

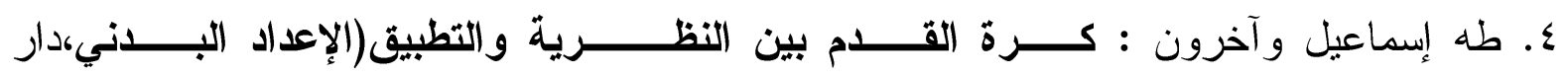

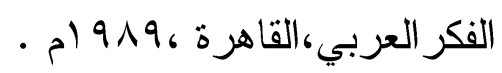

ه. عادل عبد البصير علي:"الميكانيكا الحيويه والتكامل بين النظريه والتطبيق في المجال الرياضي"، مركز الكتاب للنشر ، الطبعه الثانيه ، القاهرة ، 991 ام.

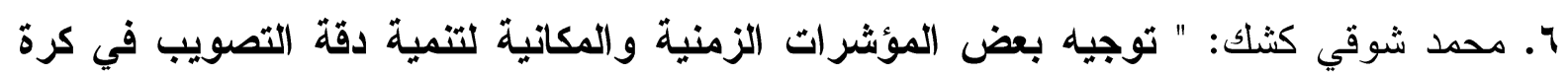

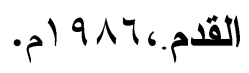

V. محمد صبحي حسانين :"القيــــاس والتقــويم في التـــــبية الرياضيــــة والرياضة"، دار

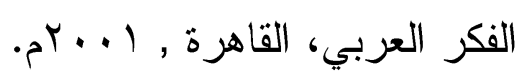
^. مفتي إبراهيم حماد : " أثر البرنامج المقترح لفترة الاعداد على كفاعة الجهاز الدورى والتففسى على لاعبى كرة القدم ، ؛ 99 ام.

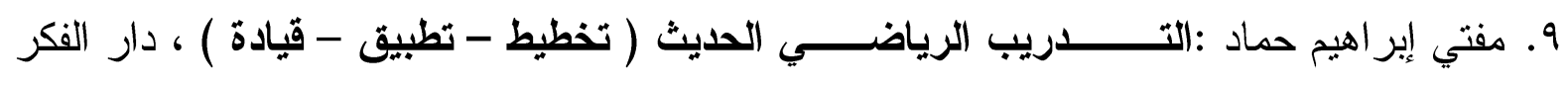

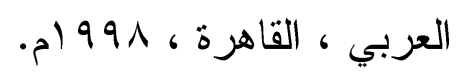

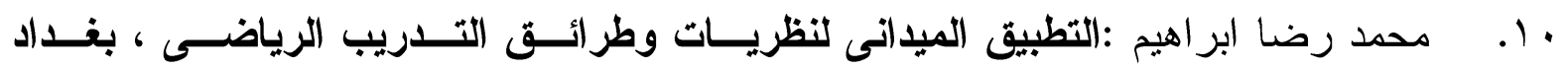
$\cdot \hat{r} \cdot \Lambda_{6}$ 